\title{
Organic Acid Effect on Calcium Uptake by the Wheat Roots
}

\author{
Fabrize Caroline Nunes, Mário Miyazawa and Marcos Antonio Pavan* \\ Instituto Agronômico do Paraná; C. P.: 481; 86001-970; Londrina - PR - Brasil
}

\begin{abstract}
This work evaluated the effect of the natural organic acids on the uptake of Ca by the wheat roots in a hydroponic solution. The following organic acids were evaluated: citric, oxalic, tartaric, malic, malonic, maleic, DL-malic, phydroxybenzoic, aconitic, and salicilic. The organic acids neither enhanced the root growth nor increased Ca uptake. The salicilic and malic acids were highly toxic and decreased the root growth. The citric, tartaric, maleic, aconitic, and salicilic decreased the Ca uptake by the roots due to their higher capacity to form the stable complexes with $\mathrm{Ca}$ in solution at $\mathrm{pH}$ 6.0. Decreasing the Ca valence from $\mathrm{Ca}^{++}$to $\mathrm{CaL}^{+}$or $\mathrm{CaL}_{2}{ }^{0}$ through the organic ligand complexation reactions decreased the Ca uptake. The results suggested that the wheat roots do not absorb Caorganic complexes.
\end{abstract}

Key words: Nutrient uptake, metal-organic complex, organic ligand, organic molecule

\section{INTRODUCTION}

Considerable attention has been dedicated on calcium (Ca) research in acid soils due to its relation with the crop productivity (Malavolta et al., 1979), root growth and water stress (Ritchey et al., 1980), fruit quality (Shear, 1975; Pavan et al., 1987; Fidalski et al., 1999), and plant vascular diseases (Cardoso et al., 1985). The Ca deficiency in the acid soil can be corrected with the lime application. The major limitation of the lime is its low efficiency to neutralize the subsoil acidity and to introduce the $\mathrm{Ca}$ deep in the soil profile. Consequently, strategies must be developed to move the alkalinity from the topsoil lime into the subsoil profile. Recent findings have reported that the plant residues left as mulch on the soil surface release a large number of organic compounds with low molecular weight, such as citric, acetic, oxalic, succinic, etc. Although these organic acids are considered to be short-lived in the soils, their

\footnotetext{
* Autor for correspondence: mpavan@iapar.br
}

continual production under the conservation agricultural systems makes their anions important in the acid soil chemistry and $\mathrm{Ca}$ transport into the soil profile (Ziglio et al., 1999; Franchini et al., 2001a; Miyazawa et al., 2002). These authors showed that due to the presence of the atomic groups in the organic molecules that posse the acidic properties, such as $-\mathrm{COOH},-\mathrm{OH},=\mathrm{NOH}$, $=\mathrm{NH},-\mathrm{NH}_{2}, \mathrm{SO}_{3} \mathrm{H}$, etc., the $\mathrm{H}^{+}$atoms may under certain circumstances $(\mathrm{pH}$, ionic strength, oxyreduction potential, etc.) be displaced by the $\mathrm{Ca}^{++}$ ions, which forms strong binding with the uncharged organic ligand $\left(\mathrm{CaL}_{2}{ }^{\circ}\right)$ or mono positively charged $\left(\mathrm{CaL}^{+}\right)$(where $\mathrm{L}=$ organic ligand). Franchini et al. (2001a) showed that the Ca organic ligand complexes are mobile in the soil profile. Chaves et al. (1991) reported that the presence of ion pair between the $\mathrm{Ca}$ and inorganic anions, such as $\mathrm{CaSO}_{4}{ }^{0}, \mathrm{CaNO}_{3}{ }^{+}$, and $\mathrm{CaCl}^{+}$, decreased the uptake of the $\mathrm{Ca}$ by coffee roots. They also found that the coffee roots absorbed preferentially free $\mathrm{Ca}^{++}$ions in solution. Thus, the question is: although the ion pair of $\mathrm{Ca}^{++}$with the 
organic anions is possible to form in the soil can the roots absorb it? Thus, the objective was to evaluate the effect of the natural organic acids on $\mathrm{Ca}$ uptake by the wheat roots.

\section{MATERIALS AND METHODS}

\section{Organic acid stock solutions}

Solution concentrations of $1.25 \times 10^{-1} \mathrm{~mol} \mathrm{~L}^{-1}$ were prepared for the following organic acids: citric $\left(\mathrm{C}_{6} \mathrm{H}_{3} \mathrm{O}_{7}\right)$, oxalic $\left(\mathrm{C}_{2} \mathrm{H}_{2} \mathrm{O}_{4}-2 \mathrm{H}_{2} \mathrm{O}\right)$, tartaric $\left(\mathrm{C}_{4} \mathrm{H}_{6} \mathrm{O}_{6}\right)$, malic $\left(\mathrm{C}_{4} \mathrm{H}_{6} \mathrm{O}_{5}\right)$, malonic $\left(\mathrm{C}_{3} \mathrm{H}_{4} \mathrm{O}_{4}\right)$, maleic $\left(\mathrm{C}_{4} \mathrm{H}_{2} \mathrm{O}_{4} \mathrm{Na}_{2}\right)$, DL $=$ malic $\left(\mathrm{C}_{4} \mathrm{H}_{6} \mathrm{O}_{5}\right)$, salicilic $\left(\mathrm{C}_{7} \mathrm{H}_{6} \mathrm{O}_{3}\right)$, p-hydroxybenzoic $\left(\mathrm{C}_{7} \mathrm{H}_{6} \mathrm{O}_{3}\right)$, and aconitic $\left(\mathrm{C}_{6} \mathrm{H}_{6} \mathrm{O}_{6}\right)$.

\section{Organic acid work solutions}

Volumes of $0.0,0.5,1.0,1.5$, and $2.0 \times 10^{-4} \mathrm{~mol} \mathrm{~L}^{-}$ 1 of each organic acid stock solution were transferred to a $250 \mathrm{ml}$ plastic beaker containing a diluted nutrient solution. The $\mathrm{pH}$ was adjusted to 6.0 with $0.01 \mathrm{~mol} \mathrm{~L}^{-1} \mathrm{HCl}$ or $0.01 \mathrm{~mol} \mathrm{~L}^{-1} \mathrm{NaOH}$. The solutions were sterilized in autoclave.

\section{Nutrient solutions}

The following salt concentrations were prepared for the nutrient solutions: $1.0 \times 10^{-4} \mathrm{~mol} \mathrm{~L}^{-1}$ $\mathrm{KH}_{2} \mathrm{PO}_{4}, 5.0 \times 10^{-4} \mathrm{~mol} \mathrm{~L}^{-1} \mathrm{KNO}_{3}, 2.0 \times 10^{-4} \mathrm{~mol}$ $\mathrm{L}^{-1} \mathrm{MgSO}_{4}$, and $5.0 \times 10^{-4} \mathrm{~mol} \mathrm{~L}^{-1} \mathrm{Ca}\left(\mathrm{NO}_{3}\right)_{2}$.

\section{Experimental procedures}

A nylon screen was placed on the top of each beaker just in contact with the nutrient solution. Three pre-germinated wheat seedlings (Triticum aestivum, cultivar Anahuac) were placed on the nylon screen. Anahuac cultivar was used because of its high $\mathrm{Ca}$ requirement. During the experimental work, the solutions were kept aerated and the evaporated water was replaced daily. After five days from the beginning of the experiment, the wheat seedlings were collected and the root elongation was measured. Then, the plant materials were dried at $65^{\circ} \mathrm{C}$ for $48 \mathrm{~h}$, digested in 1 mol $\mathrm{L}^{-1} \mathrm{HCl}$ solution and the $\mathrm{Ca}$ was determined by the Inductively Coupled Plasma (ICP). The eleven treatments were replicated four times in a completely randomized block design. All the $\mathrm{Ca}$ determinations were made in duplicate.

\section{RESULTS AND DISCUSSION}

Table 1 shows the effect of the organic acids on the means of the root length with the respective standard error. All the organic acids did not enhance the root growth. Increasing the concentrations of the salicilic and malic acids decreased drastically the root elongation in the solution. The toxic effect of the salicilic acid on the root growth was also reported by Hue et al. (1986). They also found that the salicilic acid was not able to alleviate the Al toxicity in the acid subsoil. Fig. 1 illustrates the effect of the organic acids on Ca uptake by the wheat roots. Ca uptake was not increased by the organic acids. The citric, tartaric, maleic, aconitic, and salicilic acids decreased the Ca uptake. The organic acids have the capacity to complex the metal ions in the solution which degree depends on the particular organic acid, the concentration and the type of metal, and $\mathrm{pH}$ (Jones, 1998). The solution $\mathrm{pH}$ was adjusted to 6.0 in order to increase both the $\mathrm{Ca}^{++}$ activity and the dissociation of the organic acids (Halvorson \& Lindsay, 1972; Lide, 1991-1992; Parker et al., 1995). Thus, it was expected that at pH 6.0 the $\mathrm{Ca}^{++}$ions can notreplace $\mathrm{H}^{+}$in the acid groups to form coordinated bonds with the organic molecules. The decrease in the Ca uptake in the presence of the citric, tartaric, maleic, aconitic, and salicilic acids was probably due to the higher stability constant values of their anions with the Ca ions (Martell \& Smith, 1976-1989; Lide, 19911992). It is well known that the efficiency of the organic compounds to form the complexes with the metals depends on the stability constant of the ligand (Halvorson \& Lindsay, 1972). Thus, as expected, the citrate was the most effective in decreasing the $\mathrm{Ca}$ uptake by the wheat roots due to its higher affinity for $\mathrm{Ca}^{++}$at $\mathrm{pH}$ 6.0. However, the efficiency for the organic metal complexation depends on pH. For example, Parker et al. (1995) using a speciation program GEOCHEM-PC, estimated that the Ca-citrate complex was higher at $\mathrm{pH}$ near the neutrality and decreased as the solution acidification increased. It was also unlikely that the organic acids formed precipitated in the presence of $\mathrm{Ca}$ at $\mathrm{pH}$ 6.0.

Decreasing $\mathrm{Ca}$ valence in the solution by the organic ligand complexation might influence the $\mathrm{Ca}$ uptake by the wheat roots. The effect of the ion 
valence on the $\mathrm{Ca}$ uptake has been demonstrated for coffee roots in an inorganic system by Chaves et al. (1991) who reported that decreasing the valence from $\mathrm{Ca}^{++}$to $\mathrm{CaNO}_{3}{ }^{+}, \mathrm{CaCl}^{+}$, and $\mathrm{CaSO}_{4}{ }^{\circ}$ decreased the $\mathrm{Ca}$ uptake by the coffee roots. For the organic system used in the present study, the $\mathrm{Ca}$ uptake was also affected by varying the $\mathrm{Ca}$ valence in the solution. The Ca uptake decreased with decreasing the valence from $\mathrm{Ca}^{++}$(control) to $\mathrm{CaL}^{+}$or $\mathrm{CaL}_{2}{ }^{\circ}$ (where $\mathrm{L}=$ organic ligand) in the presence of thecitric, tartaric, and salicilic acids. The importance of the valence ion on absorption by roots was suggested by Dekock \& Mitchell (1957).

Table 1 - Effect of organic acids on wheat root growth.

\begin{tabular}{lccccc}
\hline \multirow{2}{*}{ Organic acids } & \multicolumn{5}{c}{ Concentration $\times 10^{-4} \mathrm{~mol} \mathrm{~L}^{-1}$} \\
& 0.0 & 0.5 & 1.0 & 1.5 & 2.0 \\
\hline Citric & $7.8 \pm 2.7$ & $8.3 \pm 0.9$ & $8.2 \pm 2.4$ & $8.9 \pm 1.7$ & $8.7 \pm 1.7$ \\
Oxalic & $10.5 \pm 1.3$ & $10.4 \pm 2.4$ & $10.9 \pm 1.6$ & $10.3 \pm 0.6$ & $10,4 \pm 0.7$ \\
Tartaric & $10.7 \pm 1.0$ & $10.5 \pm 0.3$ & $10.5 \pm 2.6$ & $10.0 \pm 1.3$ & $9.8 \pm 1.9$ \\
Malic & $8.9 \pm 1.9$ & $8.9 \pm 2.1$ & $10.1 \pm 0.8$ & $9.5 \pm 1.8$ & $9.5 \pm 2.8$ \\
Malonic & $10.1 \pm 0.9$ & $10.7 \pm 0.9$ & $10.6 \pm 0.8$ & $10.5 \pm 1.3$ & $10.5 \pm 1.2$ \\
Maleic & $10.6 \pm 1.5$ & $8.6 \pm 1.2$ & $7.8 \pm 1.5$ & $7.4 \pm 0.8$ & $6.6 \pm 1.0$ \\
DL-Malic & $9.8 \pm 0.9$ & $10.2 \pm 1.7$ & $9.9 \pm 1.5$ & $10.0 \pm 1.2$ & $9.8 \pm 1.2$ \\
p-hydroxyb. & $10.9 \pm 2,6$ & $10.8 \pm 2.5$ & $11.1 \pm 1.6$ & $11.0 \pm 1.4$ & $10.8 \pm 0.7$ \\
Aconitic & $10.8 \pm 1.1$ & $10.9 \pm 1.8$ & $11.0 \pm 1.8$ & $11.0 \pm 2.1$ & $11.1 \pm 1.7$ \\
Salicilic & $10.0 \pm 1.2$ & $3.0 \pm 0.5$ & $2.8 \pm 0.6$ & $2.6 \pm 0.3$ & $2.5 \pm 0.3$ \\
\hline
\end{tabular}
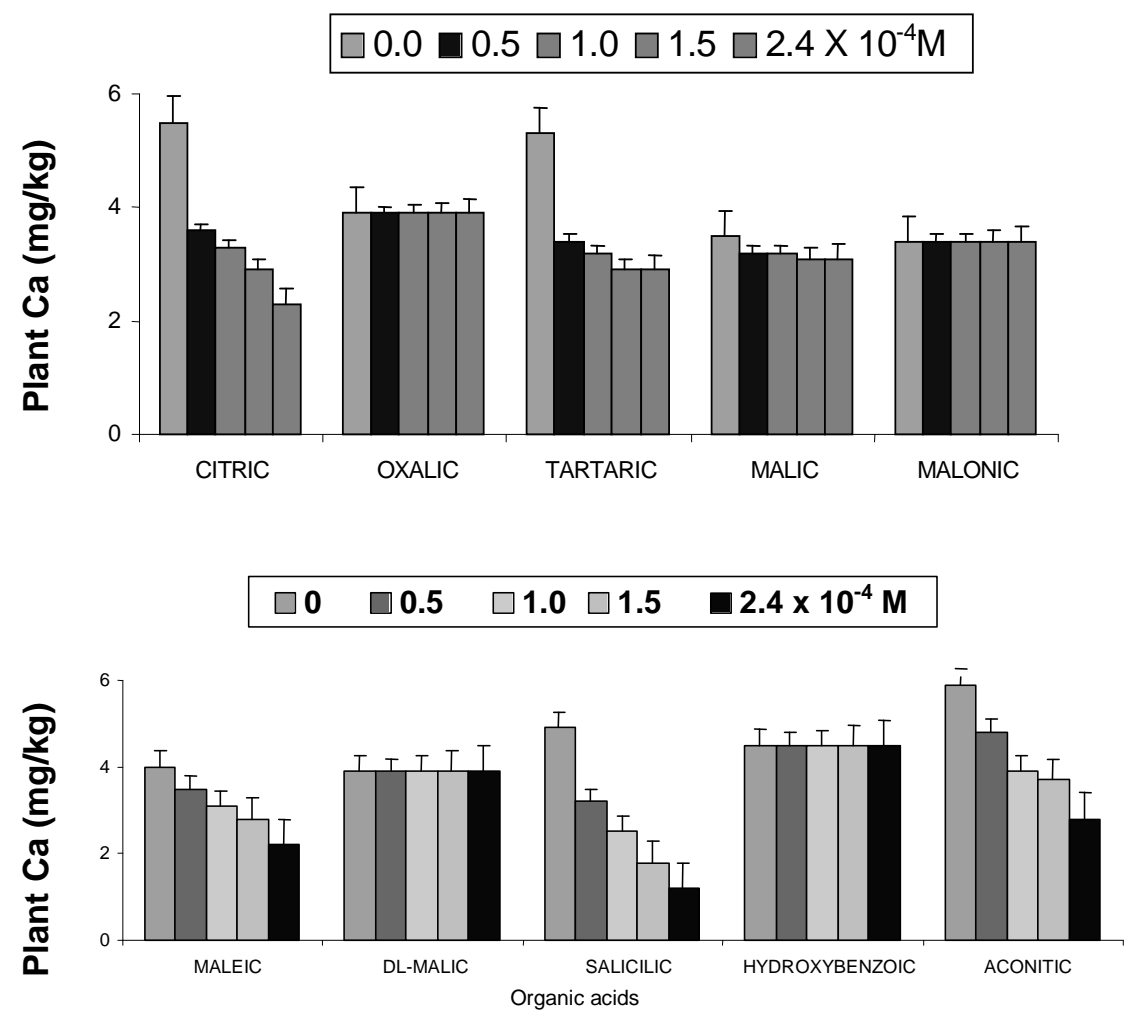

Figure 1 - Effect of organic acids on Ca uptake by wheat roots. Means of four replicates; vertical lines indicate mean standard error. 
Franchini et al. (2001a) reported that the organic compounds released by the plant residues are of short chain and form complexes with the $\mathrm{Ca}$, increasing the $\mathrm{Ca}$ transport into the subsoil profile. Although the complex reaction enhances the $\mathrm{Ca}$ transport in the soil as demonstrated by Franchini et al. (2001a), it is unlikely that the roots absorb the Ca-organic complex. However, Franchini et al. (2001b) showed that the plant residues increased not only the Ca transport into the soil profile but also the root elongation and $\mathrm{Ca}$ uptake. It seemd that in Franchini's study the Ca organic complex was formed in the alkalized topsoil layers and then moved down into the subsoil profile. In the acid subsoil layers, the $\mathrm{H}^{+}$ion displaced the $\mathrm{Ca}^{++}$from the organic complex increasing the concentration of the soluble free $\mathrm{Ca}^{++}$in the solution and consequently enhanced the $\mathrm{Ca}^{++}$uptake. The $\mathrm{Ca}^{++}$ uptake can not continue as long as the subsoil $\mathrm{pH}$ was acidic. As the alkalinity increases in the subsoil, the stability of the Ca-organic complex was increased and the $\mathrm{Ca}$ uptake by the roots should decreases.

\section{RESUMO}

Ácidos orgânicos possuem grupos funcionais com cargas negativas que complexam íons metálicos em solução. Este trabalho avaliou o efeito de ácidos orgânicos naturais na absorção de Ca pelas raízes de trigo. Foram avaliados os seguintes ácidos orgânicos: cítrico, oxálico, tartarico, málico, malônico, maleico, DL-málico, phidroxibenzoico, aconítico e salicílico. Os ácidos orgânicos não estimularam o crescimento das raízes e não aumentaram a absorção de $\mathrm{Ca}$. Os ácidos salicílico e maleico diminuíram drasticamente o crescimento radicular. Os ácidos cítrico, tartárico, maleico, aconítico e salicílico diminuíram a absorção de Ca pelas raízes devido à maior capacidade de formar complexos estáveis com $\mathrm{Ca}$ em solução no pH 6,0. A redução da valência de $\mathrm{Ca}^{++}$para $\mathrm{CaL}^{+}$e $\mathrm{CaL}_{2}{ }^{0}$, através das reações de complexação, diminuiu a absorção de $\mathrm{Ca}$ pelas raízes. Os resultados sugerem que os complexos de Ca-orgânico não são absorvidos pelas raízes de trigo.

\section{REFERENCES}

Cardoso, R.M.L.; Ota, H. and Pavan, M.A. (1985), Influência do pH e da nutrição de cálcio na incidência da murcha vascular do cafeeiro. Pesq. Agropec. Bras., 20, 447-457.

Chaves, J.C.D.; Pavan, M.A. and Miyazawa, M. (1991), Especiação química da solução do solo para interpretação da absorção de cálcio e alumínio por raízes de cafeeiro. Pesq. Agropec. Bras., 26, 447-453.

Dekock, P.C. and Mitchell, R.L. (1957), Uptake of chelate metals by plants. Soil Sci., 84, 55-62.

Fidalski, J.; Pavan, M.A.; Auler, P.A. and Jacomino, A.P. (1999), Produção de frutos de laranjeira pêra e teores de nutrientes nas folhas e no solo, em latossolo vermelho-escuro do noroeste do Paraná. Rev. Bras. Ci. Solo, 23, 273-279.

Franchini, J.C.; Gonzalez-Vila, F.J.. Cabrera, F.; Miyazawa, M. and Pavan, M.A. (2001a), Rapid transformations of plant water-soluble organic compounds in solution to cation mobilization in an acid oxisol. Pl. Soil, 231, 55-63.

Franchini,J.C.; Meda, A.R.; Cassiolato, M.E.; Miyazawa, M.. and Pavan,M.A. (2001b), Potencial de extratos de resíduos vegetais na mobilização do calcário no solo por método biológico. Scientia Agrícola, 58, 357-360.

Halvorson, A.D. and Lindsay, W.L. (1972), Equilibrium relationship of metal chelates in hydroponics solutions. Soil Sci. Soc. Am. J., 36, 755761.

Hue, N.V.; Craddock, G.R. and Adams, F. (1986), Effect of organic acids on aluminum toxicity in sub soils. Soil Sci. Soc. Am. J., 50, 28-34.

Jones, D.L. (1998), Organic acids in the rhizosphere. A critical review. Pl. Soil, 205, 25-44.

Lide, D.R. (1991-1992), CRC Handbook of chemistry and physics. $72^{\text {nd }}$ edition. Boca Raton. p.8-43.

Malavolta, E.; Dantas, J.P.; Morias, R.S. and Nogueira, F.D. (1979), Calcium problem in Latin America. Commun. Soil Sci. Pl. Anal., 10, 29-40.

Martell, A.E. and Smith, R.M. (1976-1989), Critical stability constants. 6 v. New York, Plenum Press. $305 p$.

Miyazawa, M.; Pavan M.A. and Franchini, J.C. (2002), Evaluation of plant residues on the mobility of surface applied lime. Braz. Arq. Biol. Tech. 45, 251256.

Parker, D.R.; Channey, R.L.and Novell, W.A. (1995), Chemical equilibrium models: application in plant research. In: Loeppert, R.H.; Schweb, A. P., Goldberg, S. (Eds). Chemical equilibrium and reaction models. Madison, SSSA/ASA. p. 163-200 (Special publication, 42). 
Pavan, M.A.; Bingham, F.T., Peryea, F.J. (1987), Influence of calcium and magnesium salts on acid soil chemistry and calcium nutrition of apple. Soil Sci. Soc. Am. J., 51, 1526-1530.

Ritchey, K.D.; Souza, D.M.G.; Lobato, E. and Correa, O. (1980), Calcium leaching to increase rooting depth in a Brazilian savannah oxisol. Agron. J., 72, 40-44.

Shear, C.B. (1975), Calcium nutrition and quality in fruit crops. Commun. Soil Sci. Pl. Anal., 6, 233-244.
Ziglio, C.M.; Miyazawa, M. and Pavan, M.A.; (1999), Organic and inorganic forms of calcium mobilization in soil. Braz. Arq. Biol. Tech., 42, 257-262.

Received: June 13, 2006; Revised: November 19, 2007; Accepted: May 20, 2008. 